2. Про затвердження Положення про Державну міграційну службу України: Постанова Кабінету Міністрів України від 20.08.2014 р. № 360. URL: https://zakon.rada.gov.ua/laws/show/360-2014.

3. Про Національну поліцію: Закон України від 02.07.2015 p. URL:https://zakon.rada.gov.ua/go/laws/show/580-19.

4. Конституція України: Закон України від 28.06.1996 p. № 254к/96-ВР/Верховна Рада України. Відомості Верховної Ради України. 1996. №30. Ст. 141. URL: https://zakon.rada.gov.ua/ go/254к/96вp/print.

5. Дахова I.I. Обмеження прав і свобод людини: конституційне регулювання та практика Європейського суду з прав людини. Форум права. 2018. № 4. С. 17-25.

6. Укрінформ: Мультимедійна платформа іномовлення України. URL: https://www.ukrinform.ua/rubric-society/3066785-kilkist-bizenciv-vukraini-zrostae-ostanni-pat-rokiv.html.

7. Міграція в Україні. Цифри i факти. 2019 p. URL: https://iom.org.ua/sites/default/files/iom-ukraine_facts-ukr_2019.pdf.

DOI https://doi.org/10.30525/978-9934-26-040-7-37

\title{
СИСТЕМАТИЗАЦІЯ НАУКОВИХ ПІДХОДІВ ВІТЧИЗНЯНИХ ДОСЛІДНИКІВ ДО РІВНІВ ЗАБЕЗПЕЧЕННЯ ПОДАТКОВОЇ БЕЗПЕКИ
}

\author{
Коломісць П. В. \\ кандидат юридичних наук, дочент, \\ дочент кафедри підприємництва і права \\ Полтавського державного аграрного університету \\ м. Полтава, Украӥна
}

Концепція національної безпеки України, яка була ухвалена Постановою Верховної Ради України від 16.01.1997 року № 3/97-ВР, мала закласти міцний фундамент у забезпеченні 1) єдності принципів формування і проведення державної політики національної безпеки та 2) поєднання підходів до формування відповідної законодавчої бази, підготовки доктрин, стратегій, концепцій, державних і відомчих програм у різних сферах національної безпеки. Автори цієї Концепції зазначивши, що національна безпека України досягається шляхом 150 
проведення виваженої державної політики відповідно до прийнятих доктрин, стратегій, концепцій і програм у таких сферах, як політична, економічна, соціальна, воєнна, екологічна, науково-технологічна, інформаційна тощо, визначили, що національна безпека України як стан захищеності життєво важливих інтересів особи, суспільства та держави від внутрішніх і зовнішніх загроз $є$ необхідною умовою збереження та примноження духовних і матеріальних цінностей. Тобто, у Концепції були встановлені головні об'єкти національної безпеки: громадянин - його права і свободи; суспільство - його духовні та матеріальні цінності; держава - ii конституційний лад, суверенітет, територіальна цілісність і недоторканність кордонів. При цьому законодавцем було юридично закріплено, що конкретні засоби і шляхи забезпечення національної безпеки України обумовлюються пріоритетністю національних інтересів, необхідністю своєчасного вжиття заходів, адекватних характеру і масштабам загроз цим інтересам, i грунтуються на засадах правової демократичної держави [1].

Наукова дискусія не змусила себе довго чекати. Кожен науковець висловлював свою версію забезпечення податкової безпеки, - як складової фінансової безпеки, як елементу економічної безпеки, або як вагомого чинника національної безпеки. Вітчизняні науковці доводили свої погляди на сфери забезпечення податкової безпеки, зокрема на рівні окремих громадян, суб'єктів господарювання, галузей, секторів економіки, а також на регіональному, національному та міжнародному рівнях. На сьогодні в колі наукової спільноти немає єдності думок стосовно наведених вище питань.

Поставимо завданням цього дослідження аналітичний огляд наукової літератури 3 питань податкової безпеки 3 метою систематизації наукових підходів вітчизняних дослідників до рівнів іiі забезпечення, що надасть підстави для здійснення наступної іiі типологізації:

1. Податкова безпека України (О.В. Борисюк, О.В. Стащук [2]; С.С. Голіков [3]; В.І. Глухова, Л.І. Скрипник [4]; Г.О. Лісовий [5]; I.I. Подік [6]; А.Г. Чубенко [7]).

2. Податкова безпека держави (Я.В. Лебедзевич [8]; О.В. Лепьохін, О.В. Іващенко [9]; І.С. Луценко [10]; Ю.П. Потернак [11]).

3. Податкова безпека регіону (О.С. Сушкова [12]).

4. Податкова безпека підприємства (С.О. Ареф'єв [13]; Т.О. Меліхова, О.В. Троян [14]).

5. Податкова безпека як складова бюджетної безпеки (Ю.М. Кушнірчук [15]).

6. Податкова безпека - елемент фіскальної безпеки (Г.В. Бритова, Є.В. Скрильник [16]). 
7. Податкова безпека як елемент фінансової безпеки (О.С. Веселовська [17]; В.В. Іщенко [18]; I.Р. Лукановська [19]; Л.М. Петренко [20]).

8. Податкова безпека як елемент економічної безпеки (Л.В. Ваганова [21]; О.В. Грачов [22]; В. Морунов [23]; В.М. Павліченко [24]; Ю.П. Потернак [25]; В.В. Романенко [26]; В.І. Чиж [27]).

\section{Література:}

1. Про Концепцію (основи державної політики) національної безпеки України: Постанова Верховної Ради України від 16.01.1997 р. № 3/97-ВР. Відомості Верховної Ради України. 1997. № 10. Ст. 85.

2. Борисюк О.В., Стащук О.В. Використання інструментів адміністрування податків Грузії у системі податкової безпеки: досвід для України. Вісник Національного університету «Львівська політехніка». 2017. № 875. C. 262-269.

3. Голіков С.С. Проблеми забезпечення податкової безпеки України. Інвестиції: практика та досвід. 2017. № 15. С. 62-64.

4. Глухова В.І., Скрипник Л.І. Стан податкової безпеки України та напрями ії зміцнення Міжнародний науковий журнал «Інтернаука». 2018. № 10(3). С. 15-17.

5. Лісовий Г.О. Податкова безпека України: загрози та ризики. Форум права. 2016. № 1. С. 162-168.

6. Подік I.I. Оцінювання сучасного стану податкової безпеки України. Економіка та держава. 2017. № 4. С. 46-51.

7. Чубенко А.Г. Національна податкова безпека та перспективи використання досвіду Податкової служби (IRS) Сполучених Штатів Америки для боротьби 3 тіньовою економікою в Україні. Публічне право. 2017. № 1. С. 18-25.

8. Лебедзевич Я.В. Ризики і загрози податкової безпеки держави та методи їх нейтралізації. Проблеми теорії та методології бухгалтерського обліку, контролю $і$ аналізу. Сер. : Бухгалтерський облік, контроль і аналіз. 2016. Вип. 2-3. С. 195-213.

9. Лепьохін О.В., Іващенко О. В. Вплив моделі соціальноекономічного розвитку країни на забезпечення податкової безпеки держави. Науковий вісник Херсонського державного університету. Сер. : Економічні науки. 2019. Вип. 34. С. 125-128.

10. Луценко I.C. Методичний підхід до оцінювання рівня податкової безпеки держави. Науковий вісник Херсонського державного університету. Сер.: Економічні науки. 2015. Вип. 12(2). С. 159-163.

11. Потернак Ю.П. Ризики в оподаткуванні та їх вплив на податкову безпеку держави. Науково-інформаційний вісник 
Івано-Франківського університету права імені Короля Данила Галииького. 2013. № 7. С. 338-344.

12. Сушкова O.С. Податкова безпека регіону як компроміс економічних інтересів. Молодий вчений. 2015. № 2(6). С. 1411-1414.

13. Ареф'єв С.О. Податкове адміністрування підприємства як спосіб податкової безпеки. Вісник Східноукраїнського національного університету імені Володимира Даля. 2014. № 1. С. 10-12.

14. Меліхова Т.О., Троян О.В. Аналіз впливу податкового навантаження на рівень податкової безпеки підприємства. Інвестииії: практика та досвід. 2017. № 20. С. 33-37.

15. Кушнірчук Ю.М. Реалізація фіскального потенціалу податків на економічні ресурси з метою зміцнення бюджетної безпеки. Науковий вісник НЛТУ України. 2012. Вип. 22.1. С. 273-281.

16. Бритова Г.В., Скрильник С.В. Роль бюджетно-податкової сфери у підвищенні фіскальної безпеки держави. Аспекти публічного управління. 2017. Т. 5. № 5-6. С. 44-51.

17. Веселовська О.С. Ефективне адміністрування податків як умова підтримки належної фінансової безпеки держави. Вісник Київського національного університету технологій та дизайну. 2013. № 4. C. 171-176.

18. Іщенко В.В. Податкова складова фінансової безпеки держави. Наукові праизі НДФІ. 2011. Вип. 4. С. 149-156.

19. Лукановська I.P. Теоретичне обгрунтування місця податкової безпеки в системі фінансової безпеки України. Формування ринкових відносин в Україні. 2014. № 6. С. 40-45.

20. Петренко Л.М. Податкова безпека як складова фінансової безпеки держави. Моделювання та інформаційні системи в економіці. 2012. Вип. 86. С. 89-98.

21. Ваганова Л.В. Методичні основи оцінки податкового навантаження в контексті економічної безпеки суб'єкта господарської діяльності. Вісник Запорізького національного університету. Економічні науки. 2013. № 3. С. 22-29.

22. Грачов О.В. Податкова безпека як невід'ємна складова економічної безпеки підприємства. Вісник економіки транспорту $i$ промисловості. 2010. № 29. С. 86-88.

23. Морунов В. Вплив податкового контролю як складової системи внутрішнього контролю на економічну безпеку організації. Українська наука: минуле, сучасне, майбутнє. 2014. Вип. 19(2). С. 146-154.

24. Павліченко В.М. Податкова безпека як складова економічної безпеки українських підприємств в умовах кризи. Вісник економіки транспорту і промисловості. 2015. Вип. 49. С. 131-135. 
25. Потернак Ю.П. Податковий контроль у системі забезпечення економічної безпеки держави. Науковий вісник Львівського державного університету внутрішніх справ. серія економічна. 2013. Вип. 1. C. $105-112$.

26. Романенко В.В. Негативні фактори економічної безпеки держави у контексті податкового ризик-менеджменту. Вісник Академіі митної служби України. Серія : Економіка. 2014. № 2. С. 112-119.

27. Чиж В.I. Податкове адміністрування як спосіб забезпечення економічної безпеки регіону. Економіка та право. Серія : Економіка. 2016. № 2. C. 46-52.

DOI https://doi.org/10.30525/978-9934-26-040-7-38

\title{
ГРОМАДЯНСТВО, ПАТРІОТИЗМ ТА ПРИСЯГА ПУБЛІЧНИХ СЛУЖБОВЦІВ: МОДЕЛІ ПОСДНАННЯ У СЛУЖБОВОМУ ПРАВІ КРАЇН СВІТУ
}

\author{
Коломоєць Т. О. \\ доктор юридичних наук, професор, \\ заслужений юрист України, \\ член-кореспондент Начіональної академії правових наук Украӥни, \\ декан юридичного факультету \\ Запорізького національного університету
}

Кремова Д. С. здобувач третього рівня вищої освіти кафедри адміністративного та господарського права Запорізького національного університету м. Запоріжжя, Украӥна

Аналіз положень службового права різних країн світу дозволяє із упевненістю стверджувати, що нерозривний зв'язок «громадянства публічного службовця» як обов'язкової (спеціальної) умови вступу особи на службу, «патріотизму» як одного із засадничих принципів служби і службового права в цілому й Присяги публічного службовця як певного політико-правового факту, що засвідчує «початок» відданих відносин особи під час служіння публічним інтересам. Цей 